Jacek Wojnicki

\title{
Kwestia jugosłowiańska w polityce radzieckiej i rosyjskiej (1945-1999)
}

Bałkany stanowiły tradycyjny obszar wpływów państwa rosyjskiego. Już w połowie XIX w. Imperium Rosyjskie wspierało wysiłki narodów słowiańskich (Serbów, Czarnogórców czy Bułgarów) w ich zmaganiach z tureckim okupantem. Dlatego, gdy uformowały się niezależne organizmy państwowe - Królestwo Serbii, Księstwo (a potem Królestwo) Czarnogóry oraz Królestwo Bułgarii - opcja prorosyjska we wspomnianych państwach była istotnym graczem na tamtejszych scenach politycznych ${ }^{1}$.

Polityka Zwiazku Radzieckiego wobec państw bałkańskich stanowiła kontynuację wcześniejszej polityki caratu. Józef W. Stalin dażył do wykorzystania przewagi militarnej w końcu II wojny światowej do ustanowienia strefy wpływów w państwach Europy Środkowej i Wschodniej. Bałkany

${ }^{1}$ Zob. szerzej: J. Skowronek, Sprzymierzeńcy narodów batkańskich, Warszawa 1983; idem, Polityka batkańska Hotelu Lambert (1833-1856), Warszawa 1976; M. Tanty, Rosja wobec wojen batkańskich 1912-1913, Warszawa 1970; idem, Bosfor $i$ Dardanele w polityce mocarstw, Warszawa 1982; idem, Batkany w XX wieku. Dzieje polityczne, Warszawa 2003; M. Dymarski, Konflikty na Batkanach w okresie kształtowania się państw narodowych w XIX $i$ na poczatku XX wieku, Wrocław 2010; B. Jelavich, Historia Batkanów, t. 2, Wiek XX, Kraków 2005; R. Crampton, Eastern Europe in the Twentieth Century, London-New York 1995. 
$\mathrm{w}$ tych planach odgrywały istotna rolę. Warto w tym kontekście przywołać słowa wypowiedziane przez radzieckiego dyktatora, skierowane do marszałka Josipa Broz-Tity oraz członka jugosłowiańskiego kierownictwa - Milovana Đilasa: Ta wojna nie jest taka, jak w przeszłości; kto okupuje terytorium, narzuca taki̇e swój wtasny ustrój społeczny. Każdy narzuca swój ustrój tak daleko, jak może strzec jego armia. Nie może być inaczej². Jak trafnie zauważa Henryk Bartoszewicz - polityka władców Kremla wobec omawianego regionu była częścia składową polityki europejskiej. Cele strategiczne były komplementarne - zakładały rozwój terytorialny Imperium Radzieckiego oraz poszerzanie jego strefy wpływów ${ }^{3}$.

Warto w tym miejscu odnotować propozycje, przedstawione przez angielskiego premiera, Winstona Churchilla, podczas rozmowy z radzieckim dyktatorem 9 października $1944 \mathrm{r}$. Zgodnie z nimi, wpływy ZSRR w Rumunii zostały określone na $90 \%$, w Bułgarii na 75\%, w Jugosławii i na Węgrzech na $50 \%$, a w Grecji na $10 \%$. W pozostałej części miała partycypować Wielka Brytania w porozumieniu ze Stanami Zjednoczonymi ${ }^{4}$. Stalin jednakże znacznie zmodyfikował brytyjska propozycję podziału stref wpływów $\mathrm{w}$ omawianym regionie Starego Kontynentu - zgodnie z opinią wyrażoną wobec jugosłowiańskich przywódców. W listopadzie 1944 r. Maksym Litwinow określił w piśmie do Wiaczesława Mołotowa tzw. maksymalną strefę dominacji, której Związek Radziecki powinien żądać po wojnie. Zaliczał do niej następujące kraje: Finlandię,

${ }^{2}$ M. Djilas, Rozmowy ze Stalinem, przeł. A. Ciołkosz, Warszawa 1991, s. 97.

${ }^{3}$ H. Bartoszewicz, Polityka Zwiazku Sowieckiego wobec państw Europy Środkowo-Wschodniej w latach 1944-1948, Warszawa 1999, s. 14 i nast.

${ }^{4}$ Zob. J. Tomaszewski, Europa Środkowo-Wschodnia. 1944-1968. Powstanie, ewolucja i kryzys realnego socjalizmu, Warszawa 1992, s. 17. 
Szwecję, Polskę, Węgry, Czechosłowację, Rumunię, słowiańskie kraje Pótwyspu Batkańskiego oraz Turcję ${ }^{5}$.

$\mathrm{W}$ początkowym okresie powojennym komuniści jugosłowiańscy akceptowali przewodnią rolę Związku Radzieckiego w procesie budownictwa socjalizmu, a ich partia była przeniknięta kultem Stalina. Plan pięcioletni, uchwalony w kwietniu 1947 r., wzorowany na radzieckich doświadczeniach i instytucjach, zawierał szczegółowe wytyczne dla procesu budownictwa nowego ustroju polityczno-gospodarczego Jugosławii. Partia komunistyczna miała zapewnioną całkowitą kontrolę nad wszystkimi środkami - materialnymi, kulturalnymi i politycznymi - potrzebnymi do przekształcenia społeczeństwa wiejskiego w komunistyczne państwo przemysłowe. Wyrazem zaufania Kremla do polityki Tity było wyznaczenie Belgradu na miejsce redakcji oficjalnego periodyku Biura Informacyjnego - „O trwały pokój, o demokrację ludową".

Do przełomu w stosunkach jugosłowiańsko-radzieckich doszło w 1948 r. Jednak niektórzy badacze dziejów Jugosławii doszukiwali się pierwszych symptomów niezależności kierownictwa Komunistycznej Partii Jugosławii (KPJ) w treści przemówienia Tity na wiecu w Lublanie w maju 1945 r. Ustosunkowując się do problemu uzależnienia od ZSRR, przestrzegał on przed dokonywaniem prób ingerencji w politykę państwa jugosłowiańskiego. Wystapienie Tity zostało odczytane w Moskwie jako skierowane zarówno wobec polityków zachodnich, jak i radzieckich. Niezadowolenia przywódców ZSRR dowodzi treść noty z czerwca 1945 r.: Uznajemy wystapienie towarzysza Tity za nieprzyjazne, a usprawiedliwienia towarzysza Kardelja za niezadowalajace. W przypadku ponownego ataku

${ }^{5}$ W. Zubok, K. Pleszakow, Zimna wojna zza kulis Kremla. Od Stalina do Chruszczowa, przeł. M. Koraszewska, Warszawa 1999, s. 48.

${ }^{6}$ L. Benson, Jugosławia. Historia $w$ zarysie, tłum. B. Gutowska-Nowak, Kraków 2011, s. 120-128. 
na ZSRR będziemy zmuszeni odpowiedzieć krytyka w prasie $i$ zdezawuować autorów ${ }^{7}$.

Amerykański profesor historii, Richard Raack, następująco kreślił genezę konfliktu: Tito - jego niezależnie myślacy uczeń $i$ byty sojusznik (który unikną niszczycielskiego wptywu Stalina) odkryt przyszłość, jaka chcieli mu zgotować Rosjanie ${ }^{8}$. Symptomem pogorszenia dotychczasowych relacji było wycofanie przez rząd radziecki wszystkich doradców i instruktorów wojskowych z Jugosławii ze skutkiem natychmiastowym (18 marca 1948 r.) oraz fachowców cywilnych (dzień później). Posunięcie to uzasadniane było nieprzyjaznym zachowaniem się wobec personelu wojskowego oraz odmową udzielania informacji gospodarczych radzieckiemu przedstawicielstwu handlowemu'. Tito wystosował niezwłocznie list do szefa dyplomacji - W. Mołotowa - podkreślając negatywne aspekty takich ruchów ze strony ZSRR. Prosił o ponowne rozważenie kwestii obecności doradców. Odpowiedź Stalina oraz Mołotowa przyszła, gdy Tito przebywał w Zagrzebiu. W pilnej sprawie zgłosił się do niego ambasador radziecki - Anatolij Ławrientiew. Jak wspominał jugosłowiański lider: Przyjałem go $w$ jednej $z$ willi. Stałem, czytajac ten dtugi list. Działo się we mnie coś strasznego. Bytem bardzo rozgoryczony. Potem usiadtem, ale nie poprositem, aby $i$ on usiadt. Powiedziatem mu tylko po rosyjsku, że sprawe rozważymy $i$ odpowiemy. Poza tym: do widzenia! Odwrócit się $i$ wyszedt. Napisatem wtedy przy stole dtuga odpowied $z^{10}$.

${ }^{7}$ W. Walkiewicz, Jugostawia. Państwa sukcesyjne, Warszawa 2009, s. 182.

${ }^{8}$ R. Raack, Polska i Europa w planach Stalina, przeł. P. Kościński, Warszawa 1998, s. 171.

${ }^{9}$ M. Sandulowicz, Socjalistyczna Federacyjna Republika Jugosławii, Warszawa 1982, s. 51.

${ }^{10}$ J. Woydyłł, Tito jakiego nie znamy, Warszawa [1991], s. 142. 
Oficjalne uzasadnienie zerwania bliskich „braterskich” relacji z Jugosławia znajdujemy w rezolucji Biura Informacyjnego z czerwca 1948 r.: Kierownictwo KPJ przeprowadza $w$ ostatnim czasie $w$ podstawowych zagadnieniach polityki zagranicznej $i$ wewnętrznej błędna linię, która oznacza odejście od marksizmu-leninizmu. W zwiqzku $z$ tym Biuro Informacyjne aprobuje kroki Komitetu Centralnego Wszechzwiazkowej Komunistycznej Partii (bolszewików), który wział na siebie inicjatywe ujawnienia btędnej polityki KC KPJ, a przede wszystkim tow. tow. Tito, Kardelja, Đilasa i Rankovicia ${ }^{11}$.

Podobne wypowiedzi stały się udziałem poszczególnych przywódców komunistycznych w państwach Europy Środkowej i Wschodniej. Symboliczne jest w tym względzie stwierdzenie polskiego przywódcy komunistycznego - Bolesława Bieruta, pochodzące z omawianego okresu: Tylko najgłębszym zwyrodnieniem ideologicznym można wyttumaczyć obecna postawę przywódców KPJ, którzy nie zawahali się podjać walki ze wszystkimi krajami demokracji ludowej i z ZSRR z powodu rzekomego obrażania ich godności przez krytykę ich btędnych pozycji. Odszczepienie przywódców KPJ, przynoszqce niepowetowane szkody przede wszystkim narodom Jugostawii, które wykazaty przecież wspaniata nieugiętość $i$ bohaterstwo $w$ walce $z$ imperializmem hitlerowskim, stało się sygnałem wzmożenia czujności wobec niebezpieczeństwa separatyzmu i sekciarstwa nacjonalistycznego jako rezerwy imperializmu w toczacej się dziś walce klasowej ${ }^{12}$.

Podobne deklaracje padały z ust przywódcy rumuńskich komunistów - Gheorghe Gheorghiu-Deja. Pisał on w 1949 r.: Judasz-Tito zdradza szczytne zasady internacjonalizmu

${ }^{11}$ Rezolucja Biura Informacyjnego o sytuacji $w$ Komunistycznej Partii Jugosławii, 28 czerwca 1948 r., Bukareszt, „Nowe Drogi” 1948, nr 10, s. 13.

${ }^{12}$ B. Bierut, Zjednoczenie - nowy etap w walce o lepsza przyszłość, [w:] B. Bierut, O partii, Warszawa 1952, s. 182. 
proletariackiego na rzecz sojuszu i interesów z kapitalistami amerykańskimi, angielskimi i zachodnioniemieckimi. Proletariat jugosłowiański nigdy tego nie zapomni! Trzeci zjazd Frontu Ludowego zostat zwołany przez klikę Tito w celu umocnienia antyradzieckiej polityki kierownictwa KPJ i jawnego przejścia na stroné śmiertelnych wrogów ZSRR, krajów demokracji ludowej $i$ międzynarodowego ruchu komunistycznego. W tym tkwi sens całej „filozofii” Tito o budowie socjalizmu w Jugosławii z pomoca imperializmu anglo-amerykańskiego ${ }^{13}$.

Tito po latach następująco kreślił genezę konfliktu jugosłowiańsko-radzieckiego: Zapewniajac odpowiednie warunki do budowy naszego społeczeństwa socjalistycznego, musieliśmy jednocześnie toczyć walke o niezależność $i$ równouprawnienie $w$ stosunkach międzynarodowych. Pierwszy opór Jugosławia stawiła naciskowi krajów zachodnich, a nastepnie - w roku 1948 - takize stalinowskim atakom ze strony ZSRR $i$ innych państw tzw. obozu socjalistycznego. [...] Stalin nie uznawat specyfiki społeczno-politycznego rozwoju $w$ naszym kraju. W naszej niezalė̇ności, samodzielności partii, w walce o demokratyzacje $i$ humanizacje socjalizmu stalinowcy upatrywali groźbę dla stosunków istniejacych pomiędzy krajami socjalistycznymi, a nawet dla stosunków wewnętrznych tych państw ${ }^{14}$.

Tito bronił swoich pozycji politycznych, prezentując się jako gwarant niezależności państwa jugosłowiańskiego. Podkreślał, iż został oskarżony o bycie gestapowcem $i$ sprzedajnym zdrajca ruchu komunistycznego, ponieważ, trwajac konsekwentnie przy ideałach $i$ internacjonalistycznych zasadach

${ }^{13}$ G. Gheorghiu-Dej, Klika Tito - zaciekty wróg socjalizmu, [w:] G. Gheorghiu-Dej, Artykuty i przemówienia, Warszawa 1954, s. 348.

${ }^{14} \mathrm{~J}$. Broz-Tito, Referat na uroczystym posiedzeniu IX Zjazdu ZKJ, 11 marca 1969 roku, [w:] J. Broz-Tito, Artykuły i przemówienia 1969-1975, Warszawa 1977, s. 11-35. 
ruchu komunistycznego, nie zgodzitem sie, aby nami dyrygowano, abyśmy byli zależni od drugiego, aby nasze dobra byty zagrabiane, aby nasi ludzie w swoim kraju musieli pokornie stuchać obcych, wojskowych i gospodarczych, dowódców, oddawać ustugi stużbom innych krajów ${ }^{15}$.

Do normalizacji stosunków pomiędzy Związkiem Radzieckim a Jugosławia doszło w $1955 \mathrm{r}^{16}$, kiedy to w maju do Belgradu przybyła liczna delegacja ZSRR z Nikitą Chruszczowem, Nikołajem Bułganinem, Anastasem Mikojanem i Dmitrijem Szepiłowem ${ }^{17}$. Tito przeszkodził Chruszczowowi w wygłoszeniu przemówienia powitalnego. Odsuną mikrofon i zakazał tłumaczenia fragmentu, odnoszacego się do prowokatorskiej roli Ławrientija Berii. Rozmowy okazały się trudne, bowiem delegacja radziecka nie godziła się na podkreślanie osobistej odpowiedzialności Stalina za zerwanie relacji politycznych po 1948 r. ${ }^{18}$

Do rewizyty przywódców jugosłowiańskich w Moskwie doszło w czerwcu 1956 r. Na zakończenie rozmów Chruszczow-Tito podpisano deklarację o współpracy pomiędzy obiema partiami - Komunistyczną Partią Związku Radzieckiego (KPZR) i Związkiem Komunistów Jugosławii (SKJ) - i oboma państwami. W dokumencie tym zapisano:

1. Deklaracja belgradzka z 2 czerwca 1955 r. oparta na zdrowej podstawie stosunki między obu krajami socjalistycznymi, a proklamowane w niej zasady znajduja coraz szersze zastosowanie we wzajemnej ich wspótpracy.

${ }^{15}$ Cyt. za: A. Koseski, W batkańskim tyglu, Pułtusk 2002, s. 162.

${ }^{16}$ Zob. F. Fejtô, A History of the People's Democracies. Eastern Europe since Stalin, New York-Washington-London 1971, s. 34-38.

${ }^{17}$ Krushchev Remembers, transl. and ed. by S. Talbott, with an Introduction, Commentary and Notes by E. Crankshaw, Boston-Toronto 1970, s. 375.

${ }^{18}$ R.A. Miedwiediew, Chruszczow. Biografia polityczna, przeł. W. Zagórska, Warszawa 1990, s. 83. 
2. Wspótpraca i ogólny rozwój stosunków między obu krajami po deklaracji belgradzkiej, jak również kontakty między organizacjami politycznymi i innymi organizacjami społecznymi ich narodów stworzyty pomyślne polityczne warunki również dla wspótpracy między KPZR a SKJ ${ }^{19}$.

W sposób jednoznaczny Chruszczow ukazał wizje polityki Związku Radzieckiego wobec państw Półwyspu Bałkańskiego na XX Zjeździe KPZR. W referacie sprawozdawczym mówił m.in.: Kraje Europy Południowo-Wschodniej, które $w$ swoim czasie byty dostawcami surowców i rezerw ludzkich dla Niemiec, stanowia wraz z ZSRR trwała bariere przeciwko ewentualnej agresji odwetowców niemieckich ${ }^{20}$. Rozwinięcie powyższej wykładni znajdujemy w wypowiedzi Chruszczowa podczas jego wizyty w Jugosławii latem 1963 r.: Wraz $z$ powstaniem państw socjalistycznych na Batkanach sytuacja ulegta radykalnej zmianie. Skurczyto się pole działania prowokacji imperialistycznych. Te narody batkańskie, które ujęty swoje losy we wtasne ręce, biorq aktywny udziat we wspólnej walce sit pokojowych przeciwko kapitałowi monopolistycznemu i stwarzanej przezeń groźbie wojennej ${ }^{21}$.

Przywódcy jugosłowiańscy poparli Chruszczowa podczas jego walki z grupa W. Mołotowa i Łazara Kaganowicza $\mathrm{w}$ trakcie czerwcowego plenum $\mathrm{KC} \mathrm{w}$ czerwcu $1957 \mathrm{r}^{22}$ Jego zwycięstwo przyjęto w Belgradzie z entuzjazmem, określając

${ }^{19}$ Deklaracja o stosunkach między Zwiazkiem Komunistów Jugostawii i Komunistyczna Partia Zwiazku Radzieckiego, [w:] Ekonomia i polityka Jugostawii. Zbiór artykułów, Warszawa 1957, s. 21.

${ }^{20}$ N.S. Chruszczow, Referat KC KPZR na XX Zjazd, 14 lutego 1956 roku, [w:] N.S. Chruszczow, W walce o pokój $i$ socjalizm. Wybór przemówień $i$ artykułów z lat 1956-1963, Warszawa 1964, s. 21.

${ }^{21}$ N.S. Chruszczow, $Z$ przemówienia na wiecu $w$ miejscowości Velenje, 31 sierpnia 1963 roku, [w:] ibidem, s. 726.

${ }^{22}$ Zob. F. Fejtő, op. cit., s. 91. 
„grupę antychruszczowowska” terminem „stalinizm”. Widziano w tej rozgrywce politycznej na szczytach radzieckiej władzy szansę na zdecydowane potępienie stalinizmu, także w wymiarze polityki zagranicznej ${ }^{23}$.

Tito dążył do normalizacji stosunków z ZSRR, ale nie było już mowy o bliskim sojuszu politycznym i gospodarczym. Podkreślano, w związku z przyjętą strategia, odmienności własnej, jugosłowiańskiej drogi w budownictwie socjalistycznym. W listopadzie 1957 r. delegacja komunistów jugosłowiańskich brała udział w konferencji partii komunistycznych w Moskwie. Podpisała tam jedynie ogólnikową Deklaracje o Pokoju, odmówiła natomiast sygnowania deklaracji 12 partii rządzących. Zasadniczym powodem odmowy było przekonanie o braku zbieżności pomiędzy treścią dokumentu a zasadami ideowymi i politycznymi SKJ ${ }^{24}$. Rozbieżności uległy nasileniu po VII Kongresie Związku Komunistów Jugosławii w kwietniu 1958 r. Przywódcy jugosłowiańscy przesłali projekt programu SKJ do wiadomości pozostałym partiom komunistycznym w państwach socjalistycznych. Spotkał się on z negatywną i nerwową reakcją polityków radzieckich. Organ teoretyczny KPZR „Kommunist” publicznie zaatakował projekt. Zarzucał odejście od praktyki marksizmu-leninizmu, od marksistowskiej oceny współczesnych stosunków międzynarodowych oraz marksistowskiej teorii prawa i zasad internacjonalizmu proletariackiego ${ }^{25}$.

W programie SKJ, uchwalonym na Kongresie, podkreślano znaczenie równoprawnych stosunków międzynarodowych oraz odrzucano zdecydowanie ideę monopolu ideologicznego

${ }^{23}$ Z. Brzeziński, Jedność czy konflikty, London 1964, s. 264.

${ }^{24}$ M.J. Zacharias, Komunizm, federacja, nacjonalizmy. System władzy w Jugostawii 1943-1991. Powstanie, przekształcenia, rozkład, Warszawa 2004, s. 180; F. Fejtő, op. cit., s. 92.

${ }^{25}$ M.J. Zacharias, op. cit., s. 181. 
i hegemonii politycznej jakiejkolwiek partii komunistycznej (co było wymierzone w KPZR). Inaczej uwypuklali kwestie internacjonalizmu proletariackiego - odrzucali zdecydowanie zdyscyplinowanie i podporządkowanie się partii komunistycznych jednej najważniejszej ${ }^{26}$. Jak podkreśla Zbigniew Brzeziński, gdyby przywódcy jugosłowiańscy ograniczyli się do syntetycznej wypowiedzi $\mathrm{w}$ sprawach znajdujacych się w ich własnym zakresie działania, wówczas mogliby zapewne uniknąc sprowokowania gniewu innych partii komunistycznych. Skoro jednak marksistowsko-leninowski punkt widzenia wymaga koniecznie analizy szerokich tendencji międzynarodowych, Jugostowianie nie bardzo mogli tego uniknać bez pośredniego wyrzekania się swego charakteru autentycznych marksistów-leninistów - stwierdza Brzeziński ${ }^{27}$.

W 1962 r. wizytę w Belgradzie składała delegacja parlamentu radzieckiego na czele z Leonidem Breżniewem. Zięć Chruszczowa - Aleksiej Adżubej - wspominał po latach, jak komunikat, opracowany na wspólnych posiedzeniach roboczych, został zakwestionowany w Moskwie. Doszło stamtąd polecenie, by usunąć z niego zdanie następującej treści: Delegacja radziecka zapoznata się z procesem budownictwa socjalistycznego $w$ Jugostawii. Breżniew rozmawiał telefonicznie z sekretarzem KC KPZR Frołem Kozłowem (nie udało się skontaktować z Chruszczowem), ale ten bał się podjąć wiążąca decyzję. Jaki socjalizm tam zobaczyteś? Tutaj ciebie nie zrozumieja - powiedział Kozłow. Breżniew pojechał do rezydencji, ale wrócił zdenerwowany. Powiedział reszcie delegacji: Tito wszystko zrozumiat $i$ nie dawat poznać, że to obraża towarzyszy jugostowiańskich. - Czas

${ }^{26}$ Zob. Program Zwiqzku Komunistów Jugosławii. Krytyka „Komunista”, (seria: „Biblioteka Kultury”, t. 40), Paryż 1959.

${ }^{27}$ Z. Brzeziński, op. cit., s. 271. 
osadzi, kto z nas ma racje, towarzyszu Breżniew, przekażcie to Chruszczowowi ${ }^{28}$.

Swoistym uznaniem status quo w relacjach z Jugosławia była wypowiedź Chruszczowa z trybuny Rady Najwyższej ZSRR w grudniu 1962 r.: W przeszłości Jugostowianie besztali nas, a i my nie pozostawaliśmy im dłużni. Obecnie zarówno $m y$, jak i komuniści jugostowiańscy, idziemy droga polepszenia naszych stosunków. Nie można powiedzieć, by zostały przezwyciężone wszystkie nawarstwienia $i$ trudności, jakie istniaty $w$ stosunkach wzajemnych między KPZR a SKJ. Byty i wciaż jeszcze pozostaja poważne rozbieżności co do szeregu zagadnień ideologicznych, które znalazty wyraz w programie SKJ, jak to podkreślono w Oświadczeniu narady bratnich partii. [...] Jest przy tym naturalne, i̇e każda partia komunistyczna stara się twórczo dostosowywać zasady marksizmu-leninizmu do panujacych w swym kraju konkretnych warunków historycznych, geograficznych i innych; na tej podstawie kieruje ona narodem $w$ dziele budowy socjalizmu $i$ komunizmu ${ }^{29}$.

W czasie ożywienia politycznego oraz narodowego w Chorwacji (tzw. Chorwacka Wiosna) politycy radzieccy wyrażali swój niepokój z powodu wydarzeń w federacji jugosłowiańskiej. W kwietniu 1971 r. L. Breżniew telefonował do prezydenta Tity, by przekazać zaniepokojenie wydarzeniami, które określał jako recydywę dubczekizmu (czyli tendencji reformatorskich w stylu Aleksandra Dubčeka z 1968 r.) oraz naruszenie podstaw socjalizmu $i$ jednolitego państwa. Miał także sugerować udzielenie pomocy przez ZSRR. Tito uspokajał rozmówcę, iż nie ma powodów do obaw, gdyż

${ }^{28}$ A. Adżubej, Tamte dziesięć lat. Dlaczego Chruszczow musiat odejść?, przeł. E. Biedka, Warszawa 1989, s. 218.

${ }^{29}$ N.S. Chruszczow, Referat na Sesji Rady Najwyższej ZSRR, 12 grudnia 1962 roku, [w:] N.S. Chruszczow, W walce o pokój $i$ socjalizm..., s. $626-627$. 
jugosłowiańscy przywódcy panuja nad sytuacja, a żadna pomoc nie jest potrzebna ${ }^{30}$.

We wrześniu $1971 \mathrm{r}$. oficjalną wizytę w Jugosławii złożył Breżniew. W rozmowach z gospodarzami podkreślał, iż $w$ Jugostawii ma miejsce intensywna kampania antysowiecka, prowadzona przez poszczególnych, wybitnych funkcjonariuszy politycznych i przedstawicieli środków masowego przekazu. Tito odpowiedział, że politycy radzieccy musza akceptować Jugosławię taka, jakq ona jest, bo tylko na tej podstawie można rozwijać wszechstronna wspótprace między dwoma krajami. Ale nie ukrywał, iż $w$ interesie kraju $i$ dobrych stosunków $z$ ZSRR, $w$ celu wywotania lepszego nastawienia przywódców radzieckich wobec Jugostawii, musimy usunać niektórych towarzyszy z najbardziej eksponowanych stanowisk politycznych ${ }^{31}$.

Zasady odmienności jugosłowiańskiego ustroju socjalistycznego podkreślał prezydent Tito podczas wizyty w Moskwie w 1972 r. Mówił wówczas: Wspótpraca oparta na zasadach równouprawnienia, wzajemnego szacunku, respektowania suwerenności oraz nieingerencji $w$ sprawy wewnętrzne ma wartość nieprzemijajaca ${ }^{32}$. Rozwinięcie wspomnianych zasad znajdujemy $\mathrm{w}$ toaście Tity, wygłoszonym podczas wizyty Breżniewa w Belgradzie we wrześniu $1971 \mathrm{r}$. Płaszczyznę, warunkująca pomyślny rozwój stosunków między naszymi obydwoma krajami, uzgodniliśmy już dawniej. Sktada sie na nia przede wszystkim wzajemne poszanowanie niezależności, suwerenności, integralności terytorialnej oraz nieinterwencja $w$ sprawy wewnętrzne. Sa to właśnie te zasady, które obowiazuja we wspólnocie międzynarodowej

${ }^{30}$ Zob. M.J. Zacharias, op. cit., s. 297.

${ }^{31}$ Ibidem, s. 321.

${ }^{32}$ J. Broz-Tito, Przemówienie do robotników Fabryki Łożysk Tocznych w Moskwie, 9 czerwca 1972 roku, [w:] J. Broz-Tito, Artykuty i przemówienia..., s. 100. 
i które zawarte sq w Karcie Narodów Zjednoczonych. Zasady owe sq głęboko splecione z istnieniem Jugostawii jako niezależnego $i$ niezaangażowanego kraju socjalistycznego - podkreślał prezydent Socjalistycznej Federacyjnej Republiki Jugosławii ${ }^{33}$.

Ostateczne uznanie dla odmienności jugosłowiańskiej wersji socjalizmu przyniosło „nowe myślenie”, symbolizowane przez politykę ostatniego lidera KPZR. W marcu $1988 \mathrm{r}$. wizytę w Belgradzie złożył Michaił Gorbaczow. W przyjętej na zakończenie rozmów deklaracji zapisano: Wychodzac $z$ przekonania, że nikt nie ma monopolu na prawdę, obie strony deklaruja brak roszczeń do narzucania swoich idei postepu społecznego komukolwiek innemu. Jednocześnie ZSRR i Jugostawia potwierdzaja swoje zaangażowanie $w$ polityke pokoju i niepodlegtości narodów i krajów, ich równouprawnienia, równego bezpieczeństwa wszystkich krajów, niezależnie od ich wielkości $i$ potencjatu, systemu społeczno-politycznego, idei, które je wioda oraz form i charakteru zwiqzków z innymi państwami czy ich pozycji geograficznej ${ }^{34}$. Przywódcom jugosłowiańskim Gorbaczow oświadczył, iż żadne państwo nie może narzucać modeli ustrojowych innym państwom socjalistycznym $^{35}$. Jak podkreślano w historiografii zachodniej - 14 marca 1988 r. w Belgradzie Gorbaczow przekreślił „doktrynę Breżniewa”, podnosząc kwestie niezależności partii komunistycznych w każdym państwie ${ }^{36}$.

${ }^{33}$ J. Broz-Tito, Toast na cześć sekretarza generalnego KC KPZR Leonida Breżniewa, 22 września 1971 roku, [w:] ibidem, s. 69.

${ }^{34}$ Cyt. za: Dżilas o Gorbaczowie. Rozmowa Georege'a Urbana z Milovanem Dżilasem, Warszawa 1989, s. 18; por. „Trybuna Ludu”, 19-20 III 1988.

${ }^{35}$ Zob. M. Gorbaczow, Żyzń i rieformy, Moskva 1995.

${ }^{36}$ Zob. J. Kłoczowski, Georges-Henri Soutou i jego historia zimnej wojny-wojny pięćdziesięcioletniej 1943-1990, „Rocznik Instytutu Europy Środkowo-Wschodniej” 2012, R. 10, z. 3, s. 22. 
Drugim istotnym aspektem, będącym tu przedmiotem analizy, jest stosunek polityków radzieckich/rosyjskich wobec procesu określanego jako „rozpad Jugosławii” (włącznie z krwawymi wojnami bratobójczymi, które miały tam miejsce). Dla państwa rosyjskiego, powstałego w wyniku rozpadu Związku Radzieckiego, istotne było określenie swojej polityki zagranicznej względem Bałkanów. Walka ideologiczna wewnątrz Rosji w latach 90. XX w. wywołała przekształcenie konfliktu jugosłowiańskiego z problemu polityki dyplomatycznej w przedmiot zażartych dyskusji wewnątrzpolitycznych. Generalnie uformowały się na rosyjskiej scenie politycznej dwa stanowiska. Ugrupowania komunistyczne oraz narodowopatriotyczne wykorzystywały hasła obrony interesów Rosji na Półwyspie Bałkańskim do ataków na obóz prezydenta Borysa Jelcyna oraz do wzmagania w społeczeństwie rosyjskim nastrojów antyzachodnich. Kwestia narodowych interesów Rosji na Bałkanach stała się palącym pytaniem $\mathrm{w}$ dyskursie wewnętrznym oraz w polityce zagranicznej. Zdaniem politologów o przekonaniach liberalnych oraz prozachodnich - tezy o braterstwie rosyjsko-serbskim, wykorzystywane przez komunistów oraz siły nacjonalistyczno-patriotyczne, miały w znacznym stopniu charakter mityczny ${ }^{37}$.

Należy podkreślić jeszcze jeden czynnik - prawie równoczesny rozpad federacji jugosłowiańskiej oraz Związku Radzieckiego w $1991 \mathrm{r}$. Politycy jugosłowiańscy (przede wszystkim serbscy) szukali w pierwszych miesiącach tamtego roku pomocy i wsparcia ze strony polityków oraz wojskowych w Moskwie. Symptomatyczna była w tym kontekście wizyta

${ }^{37}$ I. Kobrinskaja, Dtugi koniec zimnej wojny. Rosja i Europa Środkowa 1991-1996, Warszawa 1998, s. 27. 
szefa resortu obrony Jugosławii w ZSRR w marcu $1991 \mathrm{r}^{38}$ Jednakże politycy rosyjscy byli w ówczesnej sytuacji zajęci przekształceniami wewnętrznymi $\mathrm{w}$ ramach ZSRR (projekt nowego układu związkowego, rywalizacja Gorbaczow-Jelcyn, zakończona porozumieniem białowieskim rozwiąującym Związek Radziecki w grudniu 1991 r.). Także politycy zachodnioeuropejscy postrzegali konflikt $\mathrm{w}$ ramach federacji jugosłowiańskiej poprzez pryzmat potencjalnego rozpadu państwa radzieckiego. Proces powyższy przebiegał zatem dwufazowo, zarazem niezwykle dynamicznie ${ }^{39}$. Trafna wydaje się ocena, wyrażona przez Pawła Chmielewskiego: Jeśli porównania te mogty niepokoić radzieckie elity władzy, to wnioski musiaty wskazywać na nieuchronność procesu, zgodnie zreszta z wyznawana doktrynq o tzw. obiektywnych prawach rozwoju spoteczeństw klasowych ${ }^{40}$.

W rozwiązywaniu konfliktu jugosłowiańskiego władze Rosji (obóz prezydenta B. Jelcyna) podążały generalnie za decyzjami państw zachodnioeuropejskich. Opowiedzenie się Rosji w maju 1992 r. za sankcjami Organizacji Narodów Zjednoczonych (ONZ), wymierzonymi w Jugosławię (złożoną wówczas już tylko z dwóch republik: Serbii oraz Czarnogóry) z powodu jej agresywnej polityki wobec Bośni spowodowało atak na polityków prezydenckich w Radzie Najwyższej Federacji Rosyjskiej. Deputowani komunistyczni atakowali ministra spraw

${ }^{38}$ Zob. więcej: J. Guskova, Istorija jugoslovenske krize (1990-2000), [knj.] 1-2, Beograd 2003; eadem, Jugoslovenska kriza i Rusija. Dokumenti, fakta, komentari (1991-1995), Beograd 1996.

${ }^{39}$ P. Calvocoressi, Polityka międzynarodowa 1945-2000, przeł. W. Bolimowska-Garwacka [et al.], Warszawa 2003, s. 347 i nast.

${ }^{40} \mathrm{P}$. Chmielewski, Konflikty batkańskie pierwszej połowy lat 90. XX wieku w polityce Kremla, [w:] Bośnia i Hercegowina 15 lat po Dayton. Przeszłość - teraźniejszość - perspektywy. Studia i szkice, pod red. P. Chmielewskiego i S.L. Szczesio, Łódź 2011, s. 215. 
zagranicznych, Andrieja Kozyriewa, za opuszczenie przez Rosję tradycyjnego sojusznika na Bałkanach. Oskarżenia z powodu prozachodniej linii dyplomacji rosyjskiej koncentrowały się przede wszystkim na obronie interesu narodowego ${ }^{41}$. Można się dopatrywać trzech przesłanek decyzji rządu Rosji w sprawie sankcji skierowanych wobec Serbii i Czarnogóry: po pierwsze - wybór priorytetów, jakim było utrzymywanie dobrych relacji z Europą Zachodnią i USA; po wtóre - obawa Rosji o posądzenie jej o wspieranie siłowych rozwiązań serbskich na Bałkanach i analogicznych działań na obszarze postradzieckim; po trzecie - korzyści ekonomiczne, np. memorandum na spłatę długów odziedziczonych po ZSRR ${ }^{42}$.

Jednakże już w pierwszych latach zmian ustrojowych w Rosji (początek lat 90. XX w.) można dostrzec symptomy dwuznaczności w podejściu do Zachodu. Na posiedzeniu Rady Konferencji Bezpieczeństwa i Współpracy w Europie w Sztokholmie w grudniu 1992 r. ówczesny szef dyplomacji - A. Kozyriew - zażądał zniesienia sankcji wobec Serbii oraz obiecał pomoc wojskową dla Bośni. Później minister ten tłumaczył zachodnim partnerom, iż jego wystapienie stanowiło ostrzeżenie, jak zmieni się polityka zagraniczna po obaleniu prezydenta Jelcyna. Powyższe tłumaczenie nie przekonało jednakże obserwatorów zachodnich co do czystości intencji władz rosyjskich ${ }^{43}$.

Pewne zaskoczenie dla Zachodu stanowiła zmiana stanowiska Kremla wobec konfliktu jugosłowiańskiego. W lutym 1994 r. rosyjscy dyplomaci włączyli się w rozwiązanie kryzysu pomiędzy Serbami, oblegajacymi Sarajewo, a NATO. Wspomniane działania służyły „zachowaniu twarzy” przez Serbów, którzy dzięki rozmieszczeniu rosyjskich sił (w ramach

${ }^{41}$ S. Bieleń, Tożsamość międzynarodowa Federacji Rosyjskiej, Warszawa 2006 , s. 258.

${ }^{42}$ P. Chmielewski, op. cit., s. 220.

${ }^{43}$ S. Bieleń, op. cit., s. 257. 
kontyngentu wojsk pokojowych ONZ) w pobliżu stolicy Bośni, zastosowali się do ultimatum NATO i wycofali ciężką artylerię z okolic Sarajewa ${ }^{44}$.

Polityka Rosji wobec Serbii i ludności serbskiej w Bośni stanowiła wektor presji opinii publicznej. Jej źródła można się dopatrywać w historycznych więzach, podobieństwach religii (prawosławie) oraz przekonaniu, iż oba państwa (Rosja i Serbia) znajduja się na linii frontu wobec ekspansywnego islamu. Deputowani do rosyjskiej Dumy Państwowej wyrażali wielokrotnie swoje poparcie dla strony serbskiej, protestując zarazem przeciw sankcjom ekonomicznym i groźbom użycia sił zbrojnych wobec Serbów ${ }^{45}$.

$\mathrm{W}$ połowie lat 90 . XX w. nastapił zwrot w polityce bałkańskiej, prowadzonej przez kierownictwo Rosji. Należy to wiązać z nazwiskiem nowego szefa dyplomacji - Jewgienija Primakowa (lata 1996-1998). Stanowił on nie tylko efekt uświadomienia przez polityków zmniejszającej się roli Rosji na Bałkanach, ale także rezultat przewartościowania polityki zagranicznej Federacji Rosyjskiej. Nowa linia rosyjskiej dyplomacji w kwestii kryzysu postjugosłowiańskiego (przede wszystkim Bośni i Kosowa) sprowadzała się do prezentowania interesów rosyjskich na Bałkanach, co prowadziło do kolizji poglądów polityków Rosji i Paktu Północnoatlantyckiego ${ }^{46}$.

Wpływ na reorientację polityki dyplomacji rosyjskiej względem Półwyspu Bałkańskiego miało przejęcie odpowiedzialności za uregulowanie kryzysu bośniackiego przez NATO (poprzednio czyniły to ONZ, Unia Europejska oraz Grupa Kontaktowa - składajacca się z USA, Rosji, Wielkiej Brytanii, Francji i Niemiec). Wspomniana zmiana ujawniła

${ }^{44}$ Ibidem, s. 259.

${ }^{45}$ Ibidem.

${ }^{46}$ Zob. M. Raś, Ewolucja polityki zagranicznej Rosji wobec Stanów Zjednoczonych i Europy Zachodniej w latach 1991-2001, Warszawa 2005, s. 123. 
się w sposób zdecydowany podczas nalotów NATO na pozycje bośniackich Serbów - w celu przyjęcia przez nich bardziej ugodowego stanowiska w negocjacjach w kwestii zakończenia konfliktu w Bośni. Dyplomacja rosyjska przestała przywiązywać wagę do przyjęcia identycznych rozwiązań, jak politycy zachodnioeuropejscy ${ }^{47}$.

Kolejnym konfliktem na ziemiach postjugosłowiańskich stała się kwestia Kosowa. Ta prowincja autonomiczna w ramach Serbii była w latach 90. XX w. zamieszkiwana w $90 \%$ przez Albańczyków, co sprzyjało tendencjom odśrodkowym. Przypomnieć należy, iż na obszarze Kosowa znajdują się cenne miejsca dla historii państwa i Cerkwi serbskiej (kolebka państwowości). Konflikt ze szczególną mocą ujawnił się w marcu 1981 r., a jego nowa odsłona nastapiła pod koniec lat 80. Lider serbskich komunistów, Slobodan Milošević, postanowił wykorzystać nastroje nacjonalistyczne do umocnienia swojej władzy (np. jego wizyta na Kosowym Polu i wypowiedziane zdanie do tysięcy Serbów: Nikt nie ma prawa was bićc ${ }^{48}$.

Konflikt serbsko-albański trwał przez całe lata 90. XX w. (pozostając niejako $\mathrm{w}$ tle kolejnych krwawych wojen na ziemiach Jugosławii). Nabrał intensywności w 1998 r., gdy kosowscy Albańczycy zaczęli podkreślać znaczenie niepodległości Kosowa, a nie jak dotychczas - potrzebę szerokiej autonomii w ramach Serbii czy statusu republiki w ramach tzw. małej Jugosławii (Serbii oraz Czarnogóry). Radykalne skrzydło albańskie uformowało Wyzwoleńczą Armię Kosowa (UÇK). Jej odziały rozpoczęły w lutym 1998 r. ataki na posterunki policji serbskiej oraz gmachy urzędów. Działania UÇK spowodowały

${ }^{4}$ Ibidem.

${ }^{48}$ Zob. więcej: M. Tanty, Batkany w XX wieku...; A. Koseski, op. cit.; M. Korzeniewska-Wiszniewska, Serbia pod rzadami Slobodana Miloševicia. Serbska polityka wobec rozpadu Jugosławii $w$ latach dziewięćdziesiatych XX wieku, Kraków 2008. 
ostrą reakcję władz Serbii. Przełomowy dla konfliktu kosowskiego stał się rok 1999. Wtedy światowe media doniosły o odkryciu grobów 45 Albańczyków we wsi Račak. Morderstwo zostało potępione przez organizacje międzynarodowe, w tym przez przedstawicieli Narodów Zjednoczonych. Grupa Kontaktowa ds. byłej Jugosławii na spotkaniu 29 stycznia 1999 r. zaapelowała do Serbów oraz Albańczyków o podjęcie rozmów w oparciu o projekt planu pokojowego. Zakładał on przyznanie prowincji szerokiej autonomii, jednakże opierał się na pozostaniu Kosowa w granicach Serbii. Miejscem rozmów stał się podparyski zamek w Rambouillet. Jednocześnie NATO ostrzegło strony konfliktu, iż w przypadku odrzucenia planu pokojowego, możliwa jest interwencja zbrojna Paktu w celu ochrony ludności cywilnej ${ }^{49}$.

Strona albańska wyraziła zgodę na podpisanie porozumienia 18 marca 1999 r., natomiast władze Serbii odrzucały obie części dokumentu - polityczną i wojskowa. Taka sytuacja doprowadziła do fiaska rozmów i ich przerwania. Było to jednoznaczne ze zbrojna akcją NATO, celem wymuszenia serbskiej zgody na porozumienie. Rozpoczęła się ona 24 marca 1999 r. nocnymi bombardowaniami wybranych obiektów wojskowych i przemysłowych na obszarze całej Jugosławii. Ich druga faza, w której zakładano także ataki na jednostki wojska i policji, rozpoczęła się 28 marca $^{50}$.

Naloty lotnictwa NATO trwały 78 dni. Po zabiegach dyplomatycznych byłego premiera Rosji, Wiktora Czernomyrdina, delegata sekretarza stanu USA oraz prezydenta Finlandii - Marttiego Ahtisaariego, którzy negocjowali bezpośrednio z prezydentem Jugosławii S. Miloševiciem,

${ }^{49}$ S. Parzymies, Stosunki międzynarodowe w Europie 1945-2004, Warszawa 2004, s. 377 i nast.

${ }^{50}$ Batkany: beczka prochu bez dna?, „Rocznik Strategiczny” 1999/2000 [druk 2002], s. 202. 
uzgodniono warunki rozejmu. Problem polegał także na istnieniu rozbieżności pomiędzy stanowiskiem Rosji a NATO. Różnice dotyczyły składu i dowodzenia siłami międzynarodowymi, które miano rozlokować w Kosowie. 2 czerwca 1999 r. prezydent Milošević zaakceptował plan pokojowy. Nazajutrz został on przyjęty przez Zgromadzenie Narodowe Republiki Serbii. W przyjętym dokumencie zawarto wszystkie, dotychczas wysuwane przez Sojusz warunki: przerwanie przemocy w Kosowie, wycofanie sił serbskich z prowincji, rozmieszczenie sił międzynarodowych na podstawie rezolucji Rady Bezpieczeństwa ONZ z udziałem NATO, status autonomii dla Kosowa $\mathrm{z}$ poszanowaniem suwerenności i integralności terytorialnej Jugosławii oraz umożliwienie powrotu do domów uchodźców ${ }^{51}$.

Wiosną 1999 r. państwa Unii Europejskiej wspierały wysiłki dyplomatyczne w celu politycznego rozwiazania kryzysu. Wyrazem polityki unijnej dyplomacji było upoważnienie prezydenta Finlandii, M. Ahtisaariego, przez Radę Unii Europejskiej do zainaugurowania misji mediacyjnej $\mathrm{w}$ imieniu Unii (w porozumieniu z USA, Rosją oraz ONZ). Rezultatem misji stało się zawarcie porozumienia w kwestii Kosowa ${ }^{52}$.

Rosja uznała rozpoczęcie nalotów na Jugosławię w marcu 1999 r. za agresywną wojnę, naruszajacca podstawowe zasady prawa międzynarodowego oraz oskarżała NATO o dokonywanie ludobójstwa na ludności serbskiej. Politykom zachodnioeuropejskim zarzucała wyjątkową stronniczość przy rozwiązaniu kryzysu w Kosowie, czego wyrazem było wspieranie separatystów (terrorystów z UÇK). Dyplomacja Rosji podjęła

${ }^{51}$ J. Kiwerska, Rola Stanów Zjednoczonych w konflikcie kosowskim, seria „Zeszyty Instytutu Zachodniego” 2000, nr 18, s. 51.

${ }^{52}$ Zob. R. Zięba, Wspólna Polityka Zagraniczna i Bezpieczeństwa Unii Europejskiej, Warszawa 2007, s. 146. 
próby uchwalenia na forum Rady Bezpieczeństwa ONZ rezolucji o natychmiastowym przerwaniu nalotów. Wniosek ten został poparty przez reprezentantów Chin oraz Namibii ${ }^{33}$.

Stanowisko Rosji wyrażała opinia prezydenta B. Jelcyna $^{54}$, że Zachód uważał wojnę w Jugosławii (marzec 1999 r.) za akt odwetu, skierowany przeciwko reżimowi S. Miloševicia, natomiast Rosja traktuje wydarzenia w Kosowie jako kryzys globalny. Politycy rosyjscy oskarżali także NATO o bezkrytyczne wspieranie Albańczyków, nie troszcząc się o losy ludności serbskiej ${ }^{55}$. Jelcyn podkreślał: Owszem, konflikt $w$ Kosowie udato sie zakończyć. Ale nie rozwiazano problemów tej prowincji. Wojna wzmocnita reżim Miloševicia, choć tylko na jakiśs czas. Użycie sit międzynarodowych do rozprawy z jakimkolwiek krajem, $z$ jego mieszkańcami, jego gospodarka, jego kultura - a w Jugostawii zniszczony zostat przemyst, zabytki, światynie, muzea - to rzecz najbardziej niebezpieczna dla polityki światowej - przestrzegał rosyjski prezydent ${ }^{56}$.

Kolejna różnica dotyczyła planu stabilizacyjnego dla zbuntowanej prowincji. Rosja optowała za wprowadzeniem tam kontyngentu sił pokojowych ONZ, a nie NATO. Gdy ta propozycja została odrzucona, politycy kremlowscy zażądali własnego sektora w Kosowie, niepodlegajacego jednakże dowództwu natowskiemu. Ostatecznie USA oraz Rosja ustaliły, iż desygnowane przez Kreml siły wojskowe pozostaną pod polityczną i wojskowa kontrolą dowództwa rosyjskiego. Kontyngent ten miał pełnić specjalną rolę $\mathrm{w}$ ramach misji stabilizacyjnej KFOR, działając w sektorach amerykańskim, francuskim

${ }^{53}$ M. Raś, op. cit., s. 123.

${ }^{54}$ B. Jelcyn, Prezydencki maraton, przeł. A. Łabuszewska, Warszawa 2001, s. 225.

${ }^{55}$ Ibidem, s. 234.

${ }^{56}$ Ibidem, s. 225. 
i niemieckim, a rosyjscy oficerowie reprezentowani mieli być na wszystkich szczeblach dowodzenia ${ }^{57}$.

19 kwietnia 1999 r. Moskwa zaproponowała własny plan uregulowania konfliktu kosowskiego. Zakładał on: wycofanie $z b e ̨ d n y c h$ sit pokojowych z Kosowa oraz oddziałów NATO $\mathrm{z}$ regionów sasiadujących ze zbuntowaną prowincja (Macedonia oraz Albania); powrót wszystkich uchodźców; stworzenie warunków do działań humanitarnych na terenie Kosowa oraz pomoc gospodarczą w odbudowie ze zniszczeń wojennych. W uzupełnieniu do przedłożonego planu prezydent Jelcyn w rozmowie telefonicznej z prezydentem USA Billem Clintonem zapewnił, iż NATO daremnie liczy na kapitulację władz Jugosławii. Jelcyn wysłał do Belgradu swojego przedstawiciela - byłego premiera Czernomyrdina. Udało mu się przekonać prezydenta Miloševicia do zaakceptowania części planu pokojowego, z zastrzeżeniem, że obserwatorzy międzynarodowi nie będą pochodzić z państw NATO ${ }^{58}$. Plan spotkał się z dość chłodną reakcją polityków NATO.

Jeśli chodzi o politykę rosyjską wobec powyższych konfliktów, to w początkowym okresie (do połowy lat 90.) podażała ona bez większych zastrzeżeń za działaniami państw zachodnich. Konflikt kosowski unaocznił natomiast narastające rozbieżności pomiędzy stanowiskiem państw NATO a Kremlem.

$$
* * *
$$

Polityka radziecka po 1945 r. zakładała umieszczenie państw bałkańskich $\mathrm{w}$ swojej strefie wpływów. Zamiar ten ułatwiła pozycja Armii Czerwonej na frontach II wojny

${ }^{57}$ M. Raś, op. cit., s. 136.

${ }^{58}$ Zob. J. Kukułka, Historia wspótczesna stosunków międzynarodowych 1945-2000, Warszawa 2007, s. 766. 
światowej: większość państw regionu została „wyzwolona” przez oddziały radzieckie. Wyjątek stanowiły Jugosławia i Albania, posiadające własne, silne oddziały partyzanckie, walczące z wojskami niemieckimi i włoskimi. Przełom roku 1948 oznaczał zerwanie bliskich, niemal „braterskich”, relacji ze Związkiem Radzieckim. Przywódcy jugosłowiańscy byli określani jako stugusi imperializmu oraz zdrajcy idei marksizmu i leninizmu. Normalizacja stosunków radziecko-jugosłowiańskich nastapiła dopiero po śmierci Stalina i umocnieniu władzy przez Chruszczowa. Politycy radzieccy odwiedzili Belgrad w 1955 r., udając się jak „do Canossy”, odwołując wszystkie zarzuty o działalność rozłamowa, kierowane pod adresem titowskiego kierownictwa. Relacje radziecko-jugosłowiańskie uległy normalizacji, ale nie powróciły już do „braterskich stosunków" sprzed 1948 r. Jugosłowiańscy politycy podkreślali różnorodność dróg do socjalizmu i byli wierni własnym rozwiązaniom politycznym i gospodarczym. Przywódcy radzieccy - Chruszczow, a następnie Breżniew - musieli się z odmiennością socjalizmu samorządowego pogodzić. Zaniepokojenie sytuacja w Chorwacji na przełomie lat 60. i 70. XX w. spowodowało „przyjacielskie porady” towarzyszy radzieckich, udzielane przywódcom jugosłowiańskim. Istotnym wydarzeniem była natomiast wizyta Gorbaczowa w Belgradzie w marcu 1988 r. Polityk ten przekreślił wówczas zasadę o ograniczonej suwerenności państw bloku socjalistycznego.

Odrębnym zagadnieniem jest analiza polityki państwa rosyjskiego wobec kryzysu jugosłowiańskiego po 1991 r. Należy podkreślić „nałożenie się” na siebie dwóch wydarzeń rozpadu ZSRR oraz federacji jugosłowiańskiej. Osłabiona Federacja Rosyjska nie mogła odgrywać tak aktywnej roli na Bałkanach, jak w czasach Związku Radzieckiego. W pierwszym okresie polityka rosyjska ograniczała się praktycznie do akceptacji - choć z pewnym wahaniem - rozwiązań zaproponowanych 
przez USA i państwa Europejskiej Wspólnoty Gospodarczej/ Unii Europejskiej. Taką politykę symbolizowało nazwisko pierwszego szefa rosyjskiej dyplomacji - A. Kozyriewa. Dopiero w okresie urzędowania J. Primakowa zaznaczało się odrębne stanowisko Rosji, widoczne podczas konfliktu kosowskiego (1999 r.). Pozycja Rosji była wówczas nadal osłabiona (również kryzysem finansowym 1998 r.) i oprócz pewnych „dąsów” (jak zawrócenie samolotu z lecacym do USA szefem dyplomacji) politycy Kremla nie mogli odegrać znaczącej i samodzielnej polityki w „bałkańskiej rozgrywce”. 